\title{
ENRICHMENT AND BIOAVAILABILITY OF TOXIC ELEMENTS IN INTENSIVE VEGETABLE PRODUCTION AREAS ${ }^{1}$
}

\author{
TAINARA FERRUGEM FRANCO ${ }^{2}$, ERICA SOUTO ABREU LIMA ${ }^{2 *}$, NELSON MOURA BRASIL DO AMARAL \\ SOBRINHO $^{2}$, MARGARIDA GORÉTE FERREIRA DO CARMO ${ }^{3}$, FARLEY ALEXANDRE DA FONSECA BREDA ${ }^{2}$
}

\begin{abstract}
Vegetable cultivation stands out for intensive use of agricultural inputs due to high nutritional requirements of plants within a short period and their high susceptibility to pests and diseases. This study aimed to identify the main factors responsible for changes in pseudo-total and bioavailable contents of $\mathrm{Cd}, \mathrm{Cu}, \mathrm{Cr}$, $\mathrm{Mn}, \mathrm{Ni}, \mathrm{Pb}$, and $\mathrm{Zn}$ in soils under intensive vegetable cultivation. Soil samples were collected from 146 sites in Petrópolis (RJ), Brazil, in 2017. The samples were collected at a depth of 0-20 cm in family farm systems during vegetable production period. Pseudo-total contents of toxic elements were determined by the EPA 3050B method. Geochemical fractionation procedure was used based on the BCR method. Pollution indices were also calculated. In general, vegetable producing areas presented low contamination by $\mathrm{Cu}, \mathrm{Zn}, \mathrm{Pb}, \mathrm{Mn}$, and $\mathrm{Ni}$, except for $\mathrm{Cd}$, which showed severe contamination. In areas with the lowest slopes, most of the toxic elements showed increasing contents, reflecting relief influence. Overall, inadequate soil management, intensive application of phosphate, potassium, and organic fertilization, and relief were the most influencing parameters on the enrichment and bioavailability of toxic elements in the soil.
\end{abstract}

Keywords: Mountain farming. Contamination. Heavy metals.

\section{ENRIQUECIMENTO E BIODISPONIBILIDADE DE ELEMENTOS TÓXICOS EM ÁREAS DE PRODUÇÃO INTENSIVA DE HORTALIÇAS}

\begin{abstract}
RESUMO - O cultivo de hortaliças se destaca pelo uso intensivo de insumos agrícolas, devido à exigência nutricional em curto período de tempo e alta susceptibilidade a pragas e doenças. Este estudo teve como objetivo identificar os principais fatores responsáveis pelas alterações nos teores pseudototais e biodisponíveis de $\mathrm{Cd}, \mathrm{Cu}, \mathrm{Cr}, \mathrm{Mn}, \mathrm{Ni}, \mathrm{Pb}$ e $\mathrm{Zn}$ nos solos sob cultivo intensivo de hortaliças. Para tal, no ano de 2017, foram coletadas amostras de terra em 146 pontos no município de Petrópolis-RJ. As amostras foram coletadas na profundidade de 0-20 cm, em propriedades familiares com cultivo de hortaliças em pleno período de produção. Para determinação dos teores pseudototais dos elementos tóxicos foi utilizada a metodologia da EPA 3050B. O procedimento de fracionamento geoquímico foi realizado com base no método BCR. Também foram calculados os índices de poluição. Em geral, as áreas produtoras de hortaliças apresentaram baixa contaminação por $\mathrm{Cu}, \mathrm{Zn}, \mathrm{Pb}, \mathrm{Mn}$ e $\mathrm{Ni}$, exceto para $\mathrm{Cd}$ que apresentou severa contaminação. Nas áreas que apresentam os menores valores de declividade, houve aumento nos teores da maioria dos elementos tóxicos, refletindo a influência do relevo. De maneira geral, o manejo inadequado do solo, a aplicação intensiva de adubação fosfatada, potássica e orgânica, assim como, o revelo, foram as variáveis que mais influenciaram no enriquecimento e biodisponibilidade de elementos tóxicos no solo.
\end{abstract}

Palavras chave: Agricultura de montanha. Contaminação. Metais pesados.

\footnotetext{
${ }^{*}$ Corresponding author

${ }^{1}$ Received for publication in 09/02/2019; accepted in 01/02/2020.

Paper extracted from the master's dissertation of the first author.

${ }^{2}$ Soil Departament, Universidade Federal Rural do Rio de Janeiro, Seropédica, RJ, Brazil; ferrugem@hotmail.com - ORCID: 0000-00034348-5928, ericaabreulima@gmail.com - ORCID: 0000-0003-4140-3634, nmbdas@gmail.com - ORCID: 0000-0002-5053-7338, farleyufrrj@gmail.com - ORCID: 0000-0002-8114-1387.

${ }^{3}$ Departament of Plant Science, Universidade Federal Rural do Rio de Janeiro, Seropédica, RJ, Brazil; gorete.carmo1@gmail.com ORCID: 0000-0002-0955-091X.
} 


\section{INTRODUCTION}

Conventional horticulture is a highly intensive agricultural activity in its most varied aspects. It includes the exploration of many plant species such as leafy, root, bulb, and tuber vegetables and various fruits. However, technologies based on the intensive use of fertilizers and pesticides may cause severe damage to the environment and health of future generations (TRANI et al., 2003).

Several studies have reported accumulation of elements and/or toxic compounds at undesirable levels in agricultural soils due to intensive cultivation practices, causing soil chemical degradation and contributing to contamination of soils, water bodies, and cropped species (CHEN et al., 2015; SOUSA, 2017).

Soil contamination by toxic elements is one of the most urgent concerns in the debate on safe food and food security in the world (FAO, 2018; KONG et al., 2014). Food quality and degradation of producing areas are the main concerns both for public managers and for agricultural producers, who are faced with the responsibility of producing more and more food at affordable prices and sustainably (VIEIRA, 2011). Therefore, monitoring agricultural areas is extremely important, as increasing levels of these heavy metals in the soil represent an environmental problem, which may lead to unknown risks for future generations.

The contamination of an area is usually assessed by comparing the total contents of heavy metals found in soil with those obtained under natural conditions or reference values (standards) established by current legislation (BIONDI et al., 2011). However, the simple determination of the total or "pseudo-total" content of metals is an imprecise means of quantifying the potential risk to the environment and human health (SOARES, 2004).

The assessment of risk potential and toxicity of heavy metals in soils requires the assessment of pollutant bioavailability, which may be related to its mobility and distribution between different phases. For example, labile forms associated with watersoluble, exchangeable, and soluble-acid fractions may represent ready availability for movement in soils or absorption by organisms, while more stable pools associated with fractions bonded to $\mathrm{Fe}$ and $\mathrm{Mn}$ oxides, organic fraction, or those of high recalcitrance (residual fractions) present low bioavailability in the short- and medium-term (NASCIMENTO; FONTES; MELICIO, 2003).

This distribution (concentration) and mobility in the soil-water system can be measured by some numerical parameters used in decision-making and to direct strategies for the prevention or remediation of contaminated areas (CETESB, 2001). Extraction techniques can be used for the quantification of metals in different geochemical fractions using specific reagents in simple and/or sequential extraction schemes (SANTOS; SOUZA; SANTOS 2013).

Thus, this study aimed to identify the main factors responsible for changes in the contents of $\mathrm{Cd}$, $\mathrm{Cu}, \mathrm{Cr}, \mathrm{Mn}, \mathrm{Ni}, \mathrm{Pb}$, and $\mathrm{Zn}$ in soils under intensive vegetable cultivation in Petrópolis, RJ, Brazil, and assess the bioavailability and distribution of these metals in the different geochemical soil fractions.

\section{MATERIAL AND METHODS}

\section{Study area}

The study was conducted in areas of family farmers located in the Association of Producers of Jacó, district of Itaipava, Petrópolis, RJ, Brazil $\left(22^{\circ}\right.$ $25^{\prime} 41.64^{\prime \prime} \mathrm{S}$; $\left.43^{\circ} 02^{\prime} 54.49^{\prime \prime} \mathrm{W}\right)$. Productive units of the region are characterized as small properties, with accentuated relief, conventional soil management, and history of intensive vegetable cultivation, such as common cabbage and broccoli, with intensive use of various agrochemicals and organic residue (poultry litter).

\section{Collection and preparation of soil samples and inputs}

Collection sites were selected on family farms with vegetable cultivation in full production period. Soil samples were collected in 2017 at a depth of 0 $20 \mathrm{~cm}$ from 146 points located in 12 family properties, with a different history and management.

Soil samples were air-dried, crushed, sieved through a 2-mm-mesh sieve (air-dried fine earth) to determine chemical properties and contents of toxic elements.

Mineral and organic fertilizers most used in production areas were also sampled. Among these fertilizers are nitrogen, phosphate, and potassium fertilizers supplied through different NPK formulations, in addition to poultry litter.

The amount of poultry litter applied per hectare was estimated considering a population of 28,500 cabbage plants per hectare, with an average application of $500 \mathrm{~g}$ of fresh poultry litter with approximately $50 \%$ of moisture per plant in the planting pit.

Metal contribution from mineral fertilization and poultry litter was calculated through the average concentration of each element in the fertilizers and the average amount applied per hectare during one cabbage crop cycle.

Chemical analysis of soil samples and mineral and organic fertilizers

After preparation, these samples were analyzed for contents of organic matter (OM), organic carbon (Corg), $\mathrm{pH}\left(\mathrm{H}_{2} \mathrm{O}\right)$, exchangeable $\mathrm{Ca}$, 
$\mathrm{Mg}, \mathrm{K}$, and $\mathrm{Al}$, assimilable $\mathrm{P}, \mathrm{H}+\mathrm{Al}$ (potential acidity), sum of bases, base saturation (V), and CEC according to Embrapa method (DONAGEMMA et al., 2011).

The EPA 3050B method, described by USEPA (1996), was used to determine the contents of toxic elements in soil samples and fertilizers. The digestion method uses concentrated nitric acid, followed by hydrogen peroxide and concentrated hydrochloric acid in an open system (block digestor) at a temperature of $\pm 95^{\circ} \mathrm{C}$.

For the quality control of analytical procedures, the "pseudo-total" results of metals were compared with the certified sample SRM 2709a San Joaquim Soil certified by the National Institute of Standards and Technology (NIST, 2010), which were introduced in the analyses at random and with the same treatment as digested samples. In general, the values obtained when compared to the leached values of certified samples showed recoveries above $65 \%$, indicating the efficiency of the method.

Metal geochemical fractionation procedure was performed based on the BCR (Community Bureau of Reference) method developed by URE et al. (1993), with minor modifications to include the water-soluble fraction. Therefore, five operational geochemical fractions were considered: F1 - watersoluble fraction (extracted with deionized water); F2 - exchangeable fraction and bonded to carbonates (extracted with $0.11 \mathrm{~mol} \mathrm{~L}^{-1}$ acetic acid); F3 fraction associated with $\mathrm{Fe}$ and $\mathrm{Mn}$ oxides (extracted with $0.1 \mathrm{~mol} \mathrm{~L}^{-1}$ hydroxylamine hydrochloride at a $\mathrm{pH} \pm 2.0) ; \mathrm{F} 4$ - fraction associated with organic matter (extracted with $8.8 \mathrm{~mol} \mathrm{~L}^{-1}$ hydrogen peroxide stabilized at a $\mathrm{pH} \pm 2.0-3.0$, followed by 1.0 mol L ${ }^{-1}$ ammonium acetate solution at a $\mathrm{pH} \pm 2.0$ ); F5 - residual fraction, obtained by subtracting the results of determining the "pseudo-total" contents of heavy metals by the sum of the previous fractions (Residual fraction $=$ Pseudo-total content $-\sum F 1, F 2$, F3, and F4).

Concentrations of toxic elements in all extracts were determined by atomic absorption spectrophotometry (ABS) using the Varian 606 and OPTIMA 3000 equipment.

Limit of detection (LD) of the method was calculated by averaging the values of blanks plus three times the standard deviation of the blank of all analyses (10 replications). LD values of $0.06,0.11$, $0.01,0.08,0.003,1.00$, and $0.02 \mathrm{mg} \mathrm{kg}^{-1}$ were obtained for $\mathrm{Zn}, \mathrm{Ni}, \mathrm{Cu}, \mathrm{Pb}, \mathrm{Cd}, \mathrm{Fe}$, and $\mathrm{Mn}$, respectively.

\section{Calculation of the pollution index (PI)}

The pollution index (PI) proposed by $\mathrm{Wu}$ et al. (2015) was determined for each toxic element, according to the equation $\mathrm{PI}=\mathrm{C}$ soil $($ sample $) / \mathrm{C}$ reference, where $\mathrm{C}$ soil is the concentration of the toxic element in the soil sample at the assessed site,
$\mathrm{C}$ reference is the reference concentration of the toxic element established for the region or even the study site.

Quality reference values (QRVs) used in the present study were established by LIMA et al. (2018) for the mountainous region of the State of Rio de Janeiro.

\section{Statistical analysis}

The results were compared with soil chemical characteristics using the principal component analysis (PCA) to understand factors influencing enrichment of metals in production areas and their geochemical distribution. Other multivariate procedures were also used, such as cluster analysis and discriminant analysis. All statistical procedures were performed using the statistical program SAS version 9.2 (SAS, 2010).

A digital elevation map (DEM), based on the contour map of the study region, was elaborated for the assessment of the influence of relief and flood intensity. The covariate slope was obtained through DEM. For this, the software ArcMap 10.1, from the ArcGIS information system package was used. The topographic wetness index (TWI) was obtained using the software SAGA 2.5.

\section{RESULTS AND DISCUSSION}

\section{Supply of toxic elements by agricultural inputs}

Figure 1 shows the supply in grams per hectare of toxic elements from organic and mineral fertilizers used in agricultural properties in the Jacó River micro-basin region, the mountain region of the State of Rio de Janeiro.

Figures $1 \mathrm{~A}$ and $1 \mathrm{~B}$ show that mineral fertilization had the lowest contribution for almost all metals ( $\mathrm{Ni}, \mathrm{Co}, \mathrm{Cd}, \mathrm{Pb}, \mathrm{Cu}, \mathrm{Mn}$, and $\mathrm{Zn}$ ), except for $\mathrm{Cr}$. Phosphate and potassium fertilizers and NPK formulas are the most used in agricultural properties in the study region. Several authors have reported that natural phosphates and soluble phosphate fertilizers are the main sources of $\mathrm{Cd}$ in agricultural areas, while $\mathrm{Pb}, \mathrm{Cu}$, and $\mathrm{Zn}$ are more abundant in potassium fertilizers and NPK formulas (ZOFFOLI et al., 2013; AL-HWAITI; AL-KHASHMAN, 2015; AZZI et al., 2017).

However, organic fertilization showed the highest contribution to $\mathrm{Ni}, \mathrm{Co}, \mathrm{Cd}, \mathrm{Pb}, \mathrm{Cu}, \mathrm{Mn}$, and $\mathrm{Zn}$ (Figures 1A and 1B). The source of organic fertilizer used by all producers in the region is poultry litter. According to Testa (2018), the adoption of organic fertilizer from animal production is encouraged due to the high nutrient contents, being an alternative to reduce the consumption of agricultural input and hence reduce production costs. 

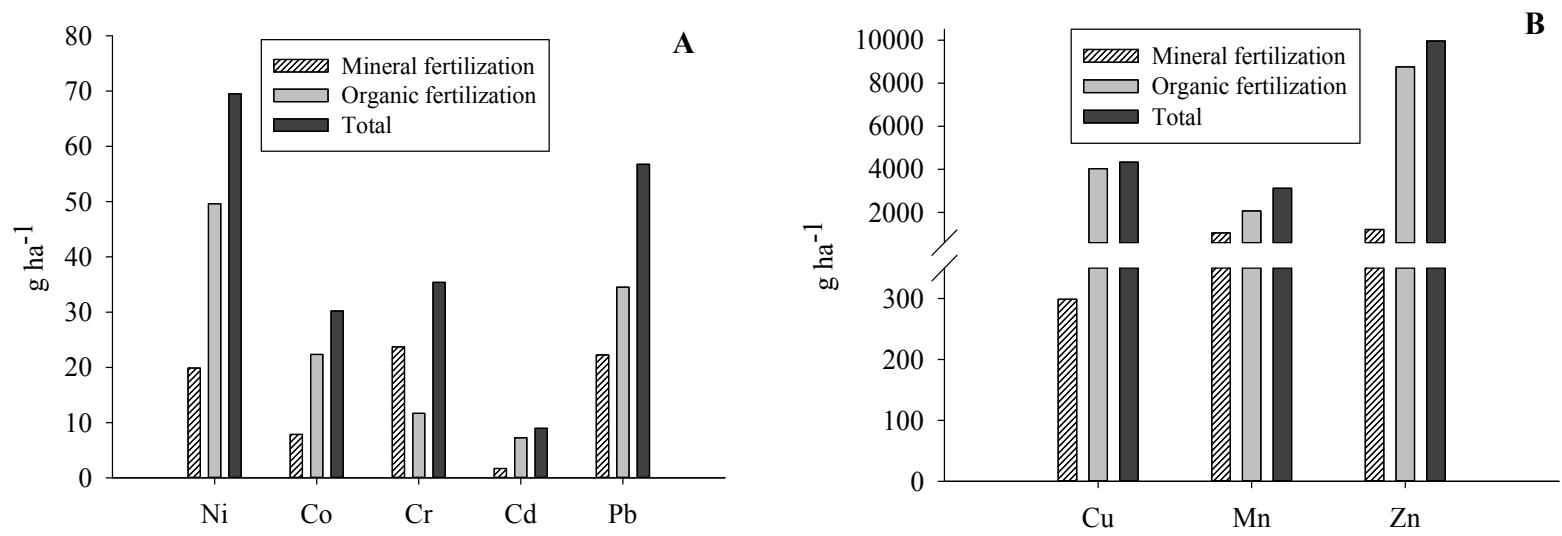

Figure 1. Supply of toxic elements in mineral and organic fertilization (A): $\mathrm{Ni}, \mathrm{Co}, \mathrm{Cr}, \mathrm{Cd}$, and $\mathrm{Pb}$; (B): $\mathrm{Cu}, \mathrm{Mn}$, and $\mathrm{Zn}$.

Poultry feed is supplemented with nutrients such as phosphorus, iron, and metals $(\mathrm{Mn}, \mathrm{Zn}, \mathrm{Cu}$, and Se), which contribute to increase feed performance and stimulate growth and weight gain. These nutrients have low assimilation, being excreted through feces and urine, being present in the manure (CODLING; CHANEY; MULCHI, 2008). The use of poultry litter at doses higher than those required can contribute to the increased risk of toxicity by toxic elements to crops and organisms of edaphic and aquatic fauna, as well as to the accumulation of phosphorus and/or nitrogen leaching (TESTA, 2018).

\section{Characterization of groups formed based on cluster analysis}

Cluster analysis was performed based on soil chemical properties $(\mathrm{Ca}, \mathrm{Mg}, \mathrm{K}, \mathrm{H}+\mathrm{Al}, \mathrm{Al}, \mathrm{CEC}$, $\mathrm{OM}, \mathrm{pH}, \mathrm{P}, \mathrm{FeT}$, and AlT) from 146 samples (Figure 2 ). The connection distance of 0.024 , which represents 1.25 times the standard deviation of the connection distance of all observations, was adopted as the cutoff point in the dendrogram for the definition of the number of formed groups (MILLIGAN; COOPER, 1985), suggesting the formation of up to 10 groups.

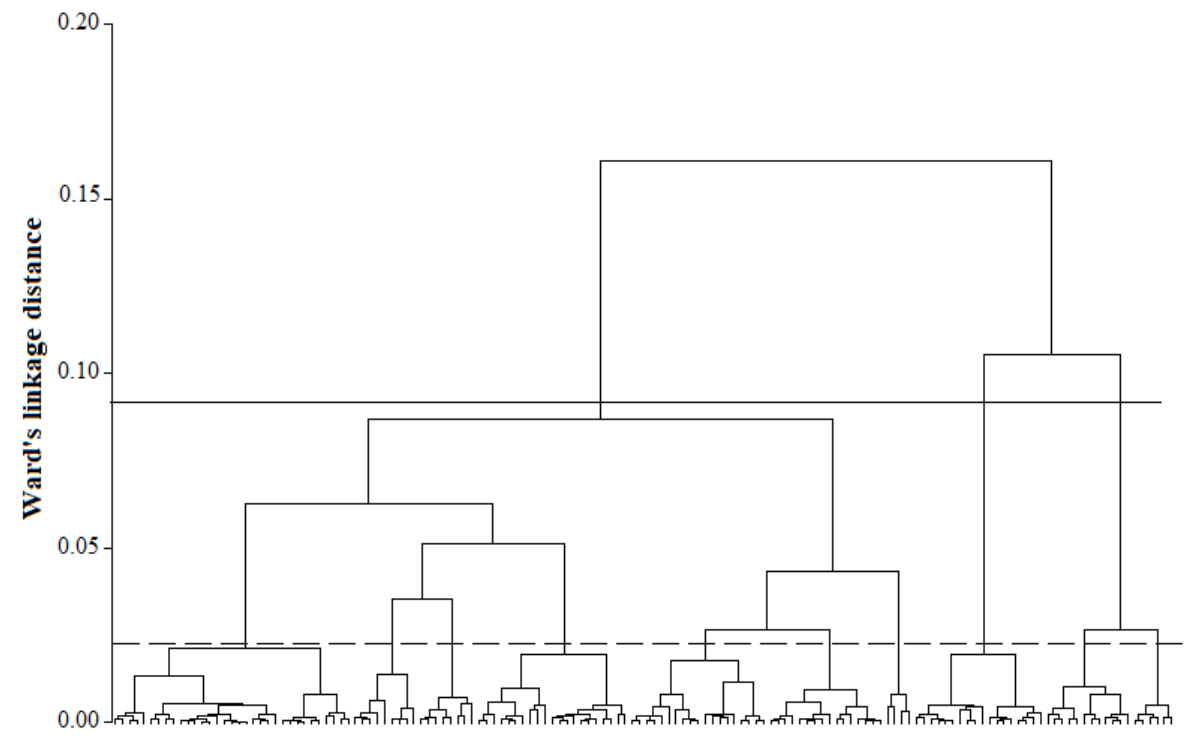

Field observation

Figure 2. Dendrogram obtained by cluster analysis based on soil chemical properties, using Ward's method and Euclidean distance.

The result of clusters was submitted to crossvalidation in the discriminant analysis (DA) to assess the choice of the number of groups and assess the overall error rate of the distribution of samples. The error rate showed that the formation with three groups would be most appropriate, as it presented the lowest overall error rate $(2.15 \%)$ of the sample distribution. Thus, three groups were formed, as follows: Group 1 (G1) with 110 observations and Group 2 (G2) and Group 3 (G3) with 18 observations each, totaling 146 samples.

Standardized data (zero mean and unit variance) of soil properties, pseudo-total and bioavailable contents of metals, pollution indexes (PI), and topographic indices (TWI, Slope, and DEM) for each group are shown in Figures 3 and 4. 


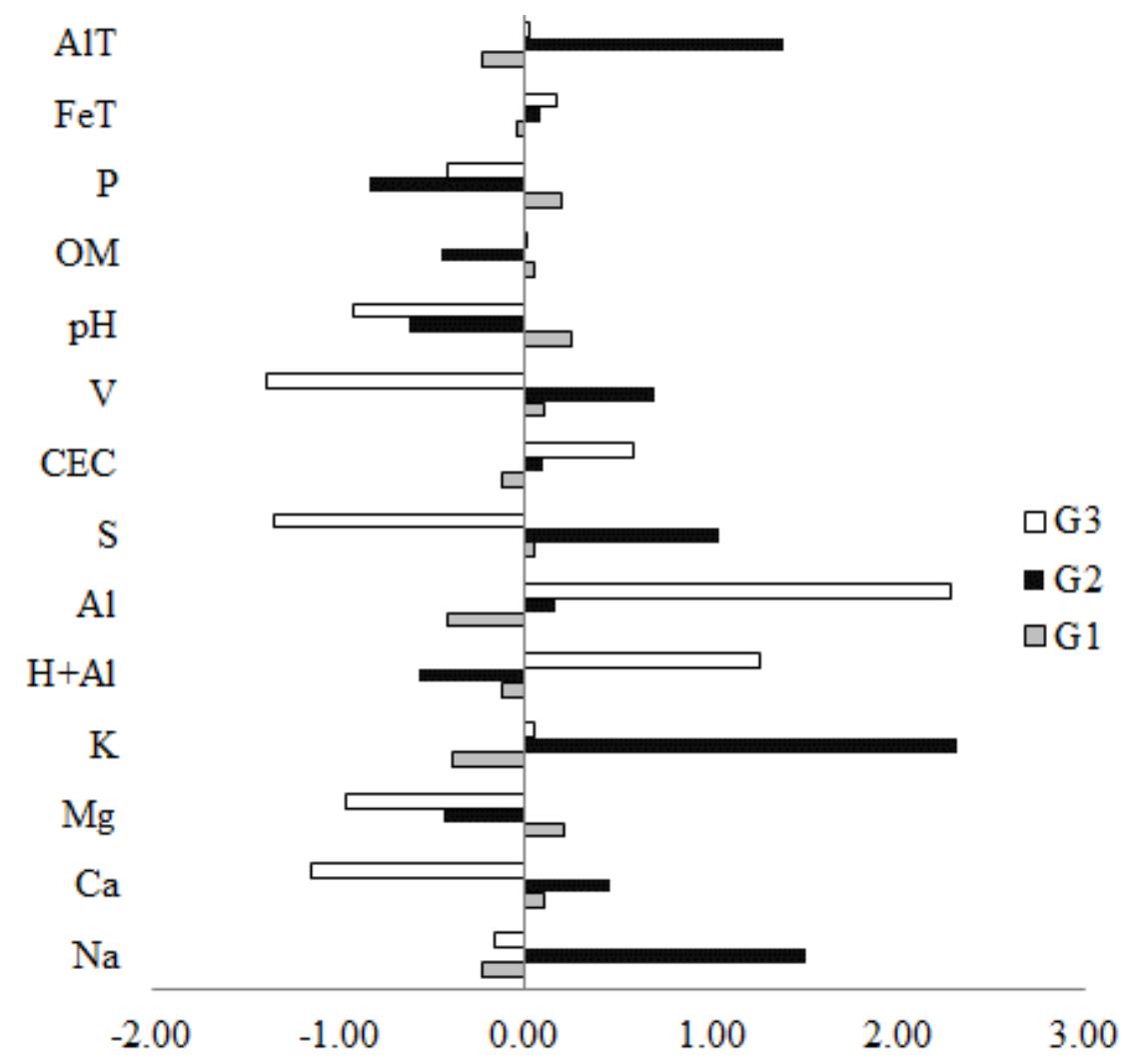

Figure 3. Standardized means of soil properties in the three groups formed by cluster analysis.
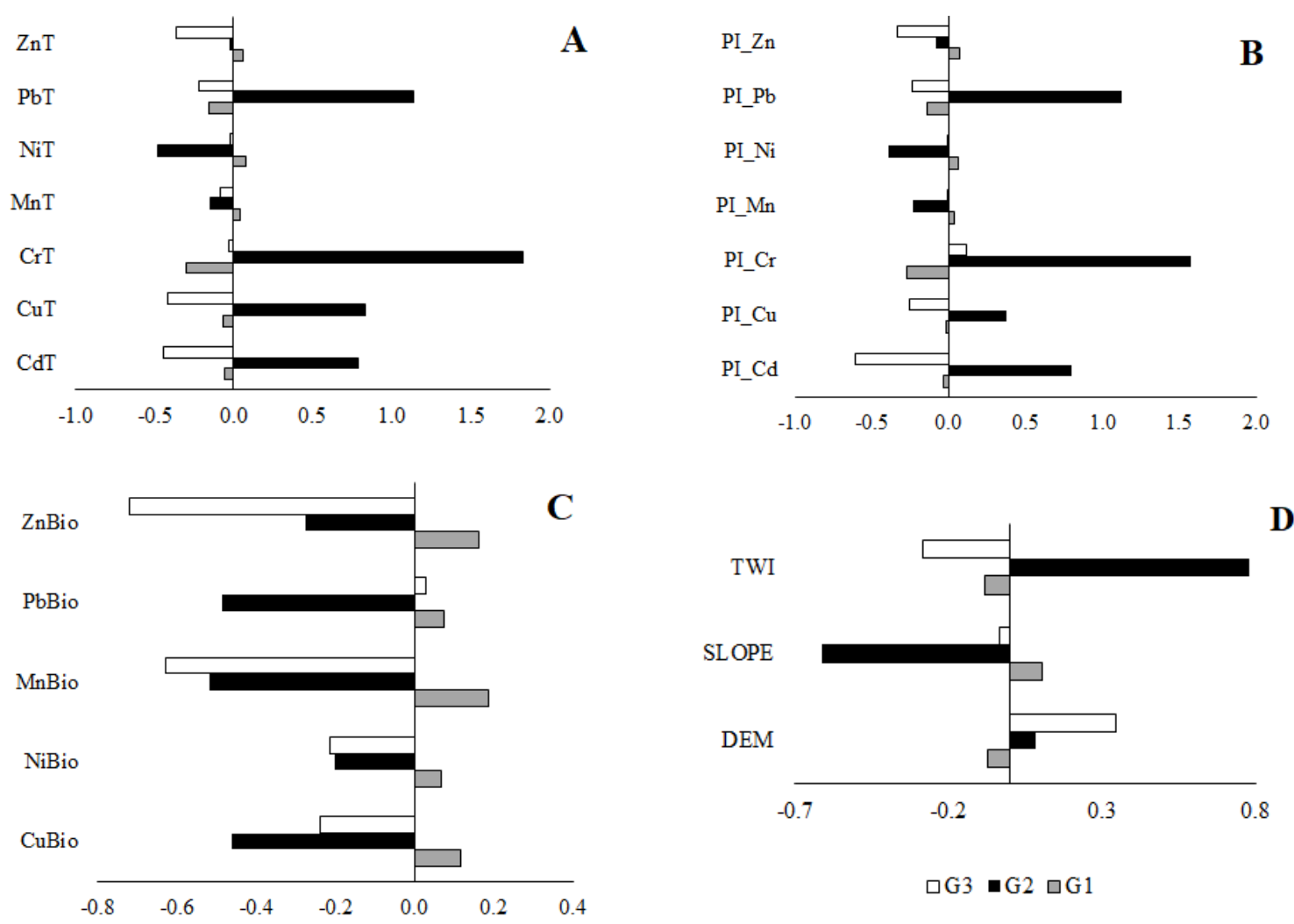

Figure 4. Standardized means of pseudo-total contents (A), pollution indices (B), and bioavailable contents (C) of toxic elements and topographic indices (D). TWI - topographic wetness index; Slope - slope; DEM - elevation. 
Group 1 (G1), characterized by the highest number of samples (110), is composed of soil samples with the highest values of $\mathrm{pH}, \mathrm{OM}, \mathrm{P}$, and $\mathrm{Mg}$ (Figure 3) and highest pseudo-total contents of $\mathrm{Zn}, \mathrm{Ni}$, and $\mathrm{Mn}$ (Figure 4A) and, consequently, the highest PIs of these metals (Figure 4B). This group also stood out for presenting the highest bioavailable contents (soluble fraction $-\mathrm{F} 1+\mathrm{F} 2$ ) among all the analyzed metals (Figure 4C).

This group also had the lowest contents of $\mathrm{Al}^{3+}$ (toxic form of aluminum), with a mean value of $0.03 \mathrm{cmol}_{\mathrm{c}} \mathrm{dm}^{-3}$, a value ten times below the critical level for the element $\left(0.3 \mathrm{cmol}_{\mathrm{c}} \mathrm{dm}^{-3}\right)$ adopted by the Rio de Janeiro State Liming and Fertilization Manual (FREIRE et al., 2013). These results confirm the information obtained in the agricultural properties, as most producers performed liming in their areas.

Organic matter content in G1 had a mean of $2.9 \%$, but some areas reached values above $6.0 \%$, an ideal value from the agronomic point of view (KIEHL, 1979). This high OM content is probably associated with organic fertilization carried out in these production areas, where the main used residue is poultry litter, also known as chicken litter or poultry manure.

The use of poultry litter as a fertilizer is economically desirable, as it represents a low-cost and easily acquired resource in the region of the rural properties, in addition to containing a high nutrient concentration. However, from an environmental perspective, its use can be allowed under major restrictions since, when applied indiscriminately and without proper previous treatment (e.g., composting), this residue can represent a potential polluter of soil and subsurface waters (SOUZA et al., 2019).

The highest contents of assimilable $\mathrm{P}$ were found in G1. These values were above the fertility class considered very high $\left(>30 \mathrm{mg} \mathrm{dm}^{-3}\right)$ for soils in the State of Rio de Janeiro (FREIRE et al., 2013), with a mean of $96.44 \mathrm{mg} \mathrm{dm}^{-3}$. Phosphate fertilizers are used to correct low $\mathrm{P}$ availability, which limits crop yields. However, it represents a potential source of contamination by metals when performed indiscriminately (BIGALKE et al., 2017).

Metal enrichment, assessed through PI, showed that only $\mathrm{Cd}$ had a mean value higher than 5 $(\mathrm{PI}=8.04)$, characterizing severe contamination (WU et al., 2015). All other elements presented mean values below 1 . However, $\mathrm{Zn}$ and $\mathrm{Ni}$ contents indicated moderate contamination in some areas despite not presenting mean values of PI above 1 when the maximum contents (4.44 and 3.61, respectively) were analyzed.

However, the main highlight of Group 1 is the high bioavailability of all elements (Figure 4C).
This high bioavailability may be related to the management adopted in these areas, mainly the indiscriminate use of soluble phosphate fertilizers, which have considerable contents of $\mathrm{Cd}, \mathrm{Cr}, \mathrm{Ni}, \mathrm{Pb}$, and $\mathrm{Zn}$, as other fertilizers, and the organic fertilization, responsible for the highest contribution of metals in the production areas.

Several studies have shown that the use of organic residues in agriculture may increase the bioavailability of metals in the soil and hence their translocation to plants (ROVEDA et al., 2014; SILVA et al., 2017). According to Barber (1995), the formation of organometallic complexes can affect the availability of cations in two opposite paths. Complexation with insoluble organic matter reduces bioavailability, while an increase may be related to the formation of soluble organometallic complexes of high stability, which influence the dynamics of metals in the soil (BARBER, 1995; PARDO; CLEMENTE; BERNAL, 2011; SILVA et al., 2017).

Group 2 (G2), with 18 observations, is characterized by the highest exchangeable contents of $\mathrm{Na}, \mathrm{K}$, and $\mathrm{Ca}$, consequently leading to higher values of sum of bases $(\mathrm{S})$ and base saturation $(\mathrm{V})$, with also the highest contents of $\mathrm{CuT}, \mathrm{PbT}, \mathrm{CrT}$, $\mathrm{CdT}$, and AlT. The areas of this group seem to be the most influenced by relief, with the lowest slope values and the highest TWI values. The highest accumulation of exchangeable bases and most metals in the lower parts may be associated with the dragging of finer soil particles by flood from the upper parts of the relief, accumulating in the lower regions. These particles, transported and deposited in the lower region of the landscape, may contain residues of agrochemicals adsorbed on soil colloids and metals such as $\mathrm{Cd}, \mathrm{Cu}, \mathrm{Pb}$, and $\mathrm{Zn}$ salts and metal-organic compounds, which usually are part of active ingredients of several agrochemicals (OWENS, 2005; ROSOLEN et al., 2009).

Potassium contents in G2 are well above the value considered very high for this element $\left(>135 \mathrm{mg} \mathrm{dm}^{-3}\right.$ ) (FREIRE et al., 2013), with mean, minimum, and maximum values of 1162.6, 800.6, and $1727.5 \mathrm{mg} \mathrm{dm}^{-3}$. Sousa (2017) also found high contents of exchangeable $\mathrm{K}$ in tomato-producing areas in the municipality of Nova Friburgo, in the mountain region of the State of Rio de Janeiro.

Despite the high accumulation of these metals, PI results in G2 indicate a low enrichment of the cultivation areas by them, with maximum PI values of 2 (for $\mathrm{Cu}$ ), indicating low contamination, according to $\mathrm{Wu}$ et al. (2015).

Group 3 (G3), as well as G2 with 18 observations, presented the lowest mean value of $\mathrm{pH}$ (5.0) and the highest values of potential acidity $(\mathrm{H}+\mathrm{Al})\left(13.79 \mathrm{cmol}_{\mathrm{c}} \mathrm{dm}^{-3}\right)$ and $\mathrm{Al}^{3+}\left(0.47 \mathrm{cmol}_{\mathrm{c}}\right.$ 
$\mathrm{dm}^{-3}$ ), which are parameters associated with soil acidity. Exchangeable aluminum contents in most of the assessed soil samples were above what is considered harmful to plants $\left(0.30 \mathrm{cmol}_{\mathrm{c}} \mathrm{dm}^{-3}\right)$ (FREIRE et al., 2013). Also, G3 was the group that had the lowest levels of exchangeable $\mathrm{Ca}$ and $\mathrm{Mg}$, indicating the lack of liming in these areas, represented by a small fraction of producers who declared not using this practice.

Regarding the pseudo-total contents of metals in $\mathrm{G} 3$, these areas had the lowest contents of $\mathrm{Cu}, \mathrm{Zn}$, $\mathrm{Pb}$, and $\mathrm{Cd}$, the highest contents of $\mathrm{FeT}$, and intermediate values of AlT. It indicates their possible association with aluminosilicates (kaolinite) and Fe and Al oxides, hydroxides, and oxyhydroxides. In other words, metal contents are possibly associated with the parent material in the region, which releases these metals into the environment when weathered.
Furthermore, most metals, except Cd, presented mean PI values below 1 and maximum values below 2 , thus most areas can be classified as non-contaminated, i.e., with less anthropogenic interference compared to QRVs obtained for the mountain region of the State of Rio de Janeiro (LIMA et al., 2018).

\section{Geochemical fractionation of metals}

Figure 5 shows the results of geochemical fractionation for the metals $\mathrm{Cu}, \mathrm{Zn}, \mathrm{Pb}, \mathrm{Mn}, \mathrm{Ni}$, and Fe, obtained by the modified BCR method. These results represent the percentage distribution in relation to the total of metals at each geochemical fraction, following the characterization previously established in the cluster analysis.
Group 1

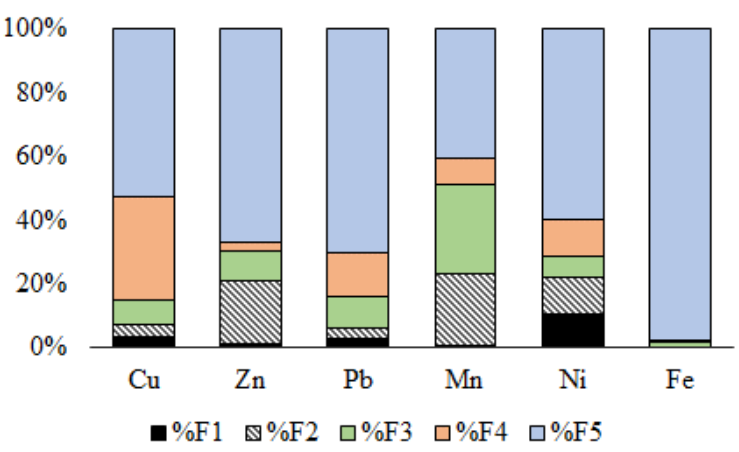

Group 2

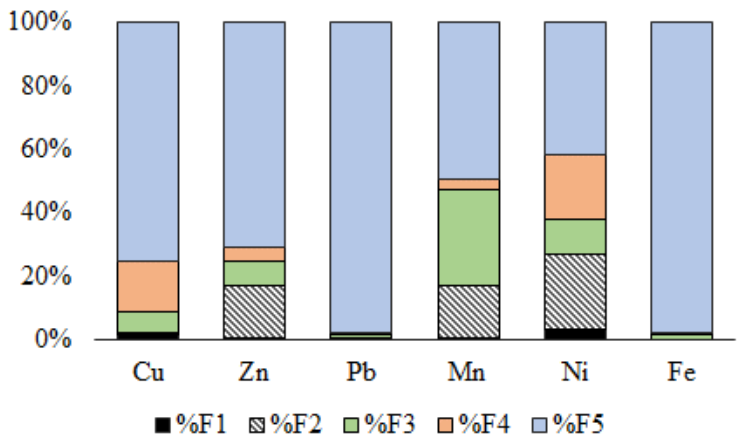

Group 3

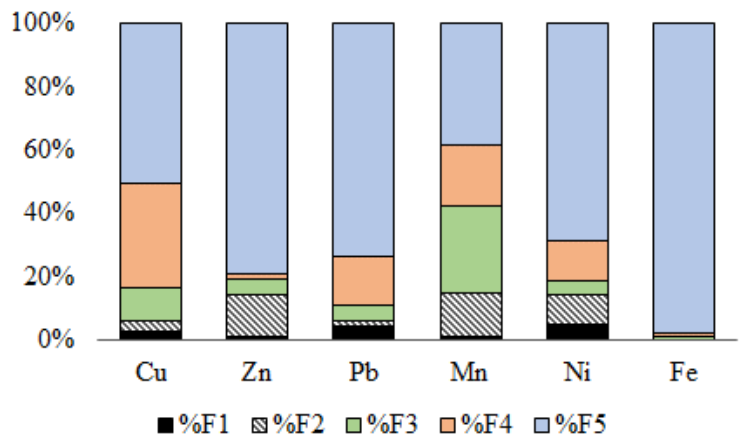

Figure 5. Percentage distribution of metals in different geochemical fractions as a function of the groups formed in the cluster analysis.

The percentage distribution of metals in different geochemical fractions showed a different behavior depending on the analyzed groups (Figure $5)$. This behavior is due to the characteristics of each soil, which reflects the management adopted in the area, as well as the chemical nature of the element, which interfere with the reactions of sorption/ desorption, precipitation/dissolution, complexation, chelation, and oxy-reduction (OLIVEIRA; MATTIAZZO, 2001). 
In general, metals showed a higher percentage in F5, the most recalcitrant fraction of the soil, which is associated with more stable bonds. According to Bevilacqua et al. (2009), metals extracted in residual fractions (F5) are fixed in the crystalline lattice of stable and resistant-to-weathering mineral silicates, thus being unavailable in the medium and/or occluded in $\mathrm{Fe}$ and $\mathrm{Al}$ oxides, hydroxides, and oxyhydroxides.

A predominance of metals was observed in the most recalcitrant soil fraction (F5), but a representative portion of metals was also observed in other fractions. Thus, metal content in other fractions was assessed to verify a possible potential for soil contamination.

The distribution of $\mathrm{Cu}$ in fractions $\mathrm{F} 1, \mathrm{~F} 2, \mathrm{~F} 3$, and F4 showed its predominance in the fraction related to soil organic matter (F4), with a value of about $30 \%$ in $\mathrm{G} 1$ and $\mathrm{G} 3$ and $16 \%$ in $\mathrm{G} 2$. This same behavior was evidenced for $\mathrm{Pb}$, which showed values close to $15 \%$ in G1 and G3. The higher retention by the organic fraction confirms the capacity of these metals to form stable complexes with the organic matter due to reactions with $\mathrm{COOH}$ and phenolic $\mathrm{OH}$ groups (STEVENSON, 1994).

The distribution of $\mathrm{Zn}$ in fractions F1, F2, F3, and F4 showed the highest percentage obtained in the three groups was observed in F2, standing out G1, which had about $20 \%$ in this fraction. The other groups (G2 and G3) presented 16 and $12 \%$, respectively. Fraction F2 added to the soluble fraction is considered the bioavailable fraction and represents the most mobile forms of metals in the environment and, consequently, with the highest potential for leaching and absorption by plants (JALALI; HEMATI, 2013).

As observed for $\mathrm{Zn}$, Ni showed predominance in the bioavailable soil fraction $(\mathrm{F} 1+\mathrm{F} 2)$ in groups G1 and G2 when compared to fractions F3 and F4, while for G3, this predominance was in F3. Group 1 showed the highest percentage of $\mathrm{Ni}$ in the watersoluble fraction (F1), with a value of about $10 \%$. This group also showed the highest pseudo-total contents of $\mathrm{Ni}$ and $\mathrm{Zn}$.

Even though the highest percentages of Mn were found in fractions F3 (fraction bound to Fe and
Mn oxides) and F5 (residual fraction), a considerable portion of this element was found in F2, especially in groups G1 and G2. This fraction is possibly associated with more soluble anthropogenic sources due to the contribution of agrochemicals (fungicides and leaf fertilizers), which have been used intensively in vegetable production areas (SOUSA, 2017).

The distribution of metals in fractions F1, F2, F3, and F4 followed their adsorption affinities, i.e., the lowest percentages of $\mathrm{Pb}$ and $\mathrm{Cu}$ in the most bioavailable fractions (exchangeable and soluble) probably occurred due to the formation of highenergy bonds (inner-sphere complexes), with the solid soil phase (organic and mineral fractions). On the other hand, $\mathrm{Ni}$ and $\mathrm{Zn}$ showed the opposite behavior, in which the highest proportions are in the bioavailable soil fraction $(\mathrm{F} 1+\mathrm{F} 2)$, mainly in the exchangeable fraction (F2), showing the predominance of low-energy bonds (outer-sphere complexes) and, therefore, capable of being moved to the soil solution.

\section{Principal component analysis between bioavailability and soil properties}

The principal component analysis (PCA) was also performed between the total contents, soil properties, and bioavailability of each metal $(\mathrm{Cu}, \mathrm{Zn}$, $\mathrm{Pb}, \mathrm{Mn}$, and $\mathrm{Ni}$ ) for a better understanding of the factors involved in the dynamics of metals in the soil.

Figure 6 shows a graphical representation of principal components (PCs). All analyzed metals $(\mathrm{Cu}, \mathrm{Zn}, \mathrm{Pb}, \mathrm{Mn}$, and $\mathrm{Ni})$ showed a direct relationship between contents of metal pseudo-total and bioavailable and assimilable $\mathrm{P}$, confirming soluble phosphate fertilizer contribution to accumulation and bioavailability of heavy metals in the soil. In addition, pseudo-total and bioavailable contents of these metals had an inverse relationship with soil properties related to adsorption such as CEC, potential acidity $(\mathrm{H}+\mathrm{Al})$, and $\mathrm{OM}$ content. Besides these parameters, FeT and AlT contents that may indicate a contribution of $\mathrm{Fe}$ and $\mathrm{Al}$ oxides, hydroxides, and oxy-hydroxides to adsorption. 


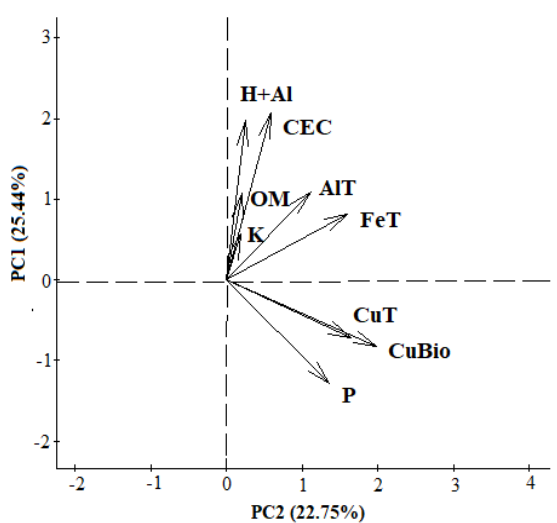

$\mathbf{A}$

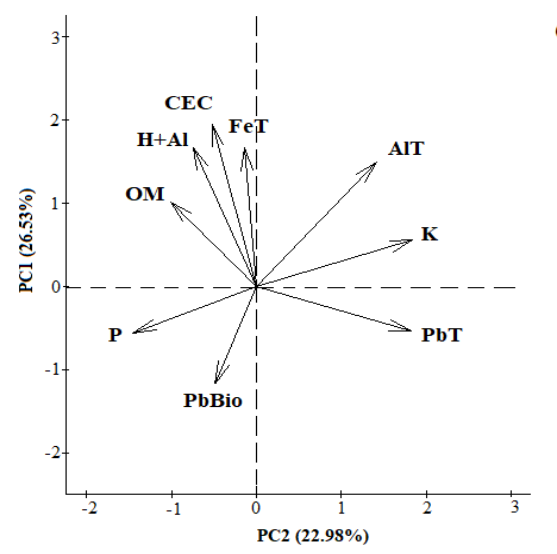

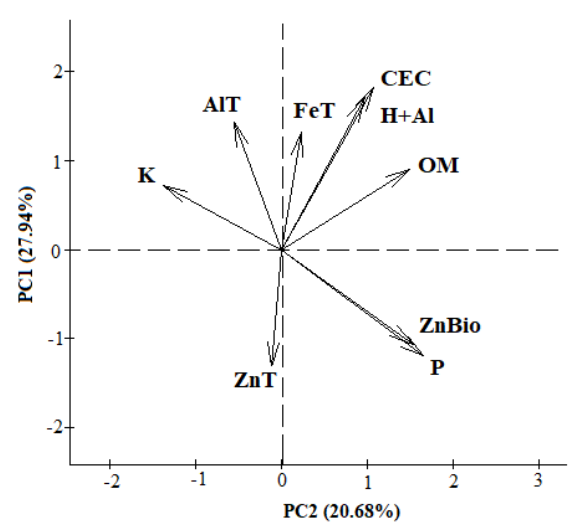

B

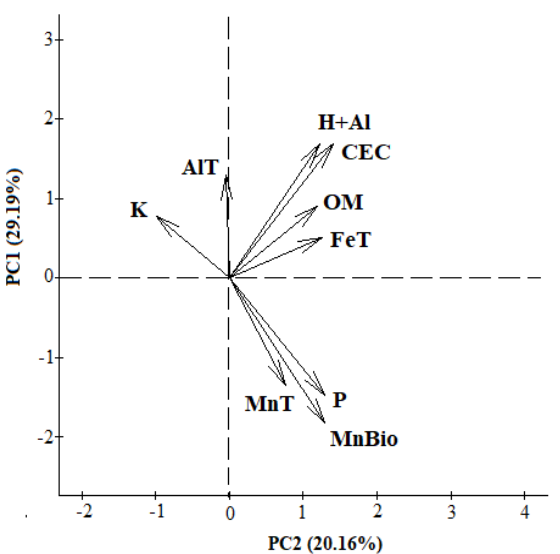

$\mathbf{E}$

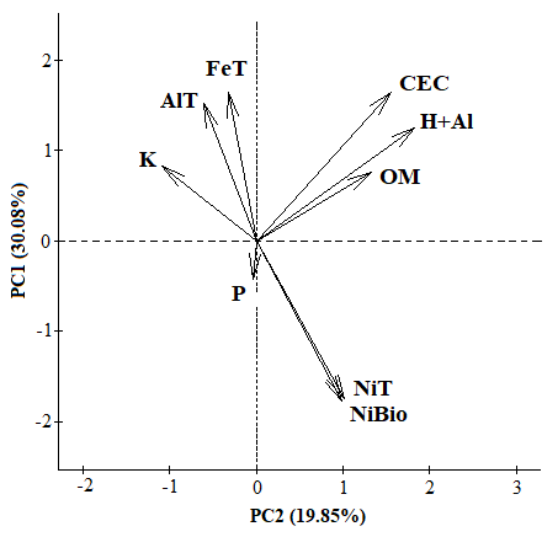

Figure 6. Graphical representation of principal components 1 (PC1) and 2 (PC2) between pseudo-total and bioavailable contents of $\mathrm{Cu}(\mathrm{A}), \mathrm{Zn}(\mathrm{B}), \mathrm{Pb}(\mathrm{C}), \mathrm{Mn}(\mathrm{D})$, and $\mathrm{Ni}(\mathrm{E})$.

Our results demonstrate that, although contribution of toxic elements via organic fertilization (poultry litter) is superior to that via mineral fertilization (Figure 1), the high solubility of mineral inputs possibly caused a high influence on the availability of these elements. In addition, poultry litter is applied fresh, possibly with a low decomposition stage, favoring the predominance of forms not yet available of toxic elements.

Moreover, organic matter can act in two ways by complexing with insoluble organic matter, reducing availability, or forming soluble complexes, especially with fulvic acids, increasing metal availability (BARBER, 1995). Thus, studies related to the characterization and fractionation of humic substances in the soil organic matter would be necessary for a better assessment of the contribution of OM from the organic fertilizer in the adsorption or bioavailability of metals, as the total content was not an adequate parameter for this assessment.

Silva et al. (2017) observed that among humic substances in soil organic matter, fulvic acids form highly stable complexes with lead, increasing its solubility and bioavailability in the soil, potentiating risks of contamination of water bodies and transference to the trophic chain. 


\section{CONCLUSIONS}

In general, vegetable producing areas showed low contamination by metals $\mathrm{Cu}, \mathrm{Zn}, \mathrm{Pb}, \mathrm{Mn}$, and $\mathrm{Ni}$, except for $\mathrm{Cd}$, which presented severe contamination.

Areas with the lowest slope and highest TWI values showed an increase in the contents of most toxic elements, thus reflecting the influence of relief.

The bioavailability of $\mathrm{Cu}, \mathrm{Zn}, \mathrm{Pb}, \mathrm{Mn}$, and $\mathrm{Ni}$ is possibly related to the intensive application of phosphate, potassium, and organic fertilizer in the areas, which also contribute to the total accumulation of these metals.

Metal distribution in the different geochemical fractions followed their adsorption affinities, in which $\mathrm{Pb}$ and $\mathrm{Cu}$ are associated with more stable fractions due to the formation of highenergy bonds with the solid soil phase. On the other hand, $\mathrm{Ni}$ and $\mathrm{Zn}$ are associated with the bioavailable soil fraction, showing the predominance of lowenergy bonds capable of being displaced to the soil solution, representing a high risk of contamination of water bodies and transference to the trophic chain.

\section{REFERENCES}

AL-HWAITI, M. S., AL-KHASHMAN, O. A. Health risk assessment of heavy metals contamination in tomato and green pepper plants grown in soils amended with phosphogypsum waste materials. Environmental Geochemistry and Health, 37: 287-304, 2015.

AZZI, V. et al. Trace Metals in Phosphate Fertilizers Used in Eastern Mediterranean Countries: Soil. CLEAN - Soil, Air, Water, 45: 1-8, 2017.

BARBER, S. A. Soil nutrient bioavailability: a mechanistic approach. 2. ed. New York, NY: John Wiley \& Sons, 1995. 414 p.

BEVILACQUA, J. E. et al. Extração seletiva de metais pesados em sedimentos de fundo do Rio Tietê, São Paulo. Química Nova, 32: 26-33, 2009.

BIGALKE, M. et al. Accumulation of cadmium and uranium in arable soils in Switzerland. Environmental Pollution, 221: 85-93, 2017.

BIONDI, C. M. et al. Teores de Fe, Mn, Zn, Cu, Ni e Co em solos de referência de Pernambuco. Revista Brasileira de Ciência do Solo, 35: 1057-1066, 2011.

CHEN, C. S. et al. The Ability of Immobilized Bacterial Consortia and Strains from River Biofilms to Degrade the Carbamate Pesticide Methomyl".
International Journal of Environmental Science and Technology, 12: 2857-2866, 2015.

CODLING, E. E.; CHANEY, R. L.; MULCHI, C. L. Effects of Broiler Litter Management Practices on Phosphorus, Copper, Zinc, Manganese, and Arsenic Concentrations in Maryland Coastal Plain Soils. Communications in Soil Science and Plant Analysis, 39: 1193-1205, 2008.

COMPANHIA DE TECNOLOGIA DE SANEAMENTO AMBIENTAL - CETESB. Manual de gerenciamento de áreas contaminadas. 2. ed. São Paulo, SP: CETESB, 2001. 389 p.

DONAGEMMA, G. et al. Manual de métodos de análise de solos. 2. ed. Rio de Janeiro, RJ: Embrapa Solos, 2011. 230 p. (Documentos, 132).

FOOD AND AGRICULTURE ORGANIZATION OF THE UNITED NATIONS - FAO. Building climate resilience for food security and nutrition. Rome: FAO, 2018.

FREIRE, L. R. et al. Manual de calagem e adubação do Estado do Rio de Janeiro. 1. ed. Brasília, DF: Embrapa, 2013. 430 p.

JALALI, M.; HEMATI, N. Chemical fractionation of seven heavy metals $(\mathrm{Cd}, \mathrm{Cu}, \mathrm{Fe}, \mathrm{Mn}, \mathrm{Ni}, \mathrm{Pb}$, and $\mathrm{Zn}$ ) in selected paddy soils of Iran. Paddy and Water Environment, 11: 299-309, 2013.

KIEHL, E. J. Manual de edafologia: relação solo planta. 1. ed. São Paulo, SP: Agronômica Ceres, 1979. $262 \mathrm{p}$.

KONG, W. et al. Removal of heavy metals from aqueous solutions using acrylic-modified sugarcane bagasse-based adsorbents: equilibrium and kinetic studies. Bioresources, 9: 3184-3196, 2014.

LIMA, E. S. A. et al. Soil heavy metal content on the hillslope region of Rio de Janeiro, Brazil: reference values. Environmental Monitoring and Assessment, 190: 1-11, 2018.

MilligAN, G. W., COOPER, M. C. An examination of procedures for determining the number of cluster in a data set. Psychometrika, 50: 159-179, 1985.

NASCIMENTO, C. W. A. DO; FONTES, R. L. F.; MELICIO, A. C. F. D. Copper availability as related to soil copper fractions in oxisols under liming. Scientia Agricola, 60: 167-173, 2003.

NATIONAL INSTITUTE OF STANDARDS AND TECHNOLOGY - NIST. Certification of Three NIST Renewal Soil Standard Reference Materials 
for Element Content: SRM 2709a San Joaquin Soil, SRM 2710a Montana Soil I, and SRM 2711a Montana Soil II. p. 39, 2010.

OLIVEIRA, F. C.; MATTIAZZO, M. E. Mobilidade de metais pesados em um Latossolo Amarelo distrófico tratado com lodo de esgoto e cultivado com cana-de-açúcar. Scientia Agricola, 58: 807$812,2001$.

OWENS, P. Conceptual models and budgets for sediment management at the river basin scale (12 pp). Journal of Soils and Sediments, 5: 201-212, 2005.

PARDO, T.; CLEMENTE, R.; BERNAL, M. P. Effects of compost, pig slurry and lime on trace element solubility and toxicity in two soils differently affected by mining activities. Chemosphere, 84: 642-650, 2011.

ROSOLEN, V. et al. Qualidade dos sedimentos no rio Uberabinha (Uberlândia, MG) e implicações ambientais. Revista Brasileira de Geociências, 39: 151-159, 2009.

ROVEDA, L. F. et al. Composto orgânico com altos teores de níquel e sua biodisponibilidade no sistema solo planta. Revista Brasileira de Engenharia Agricola e Ambiental-Agriambi, 18: 819-825, 2014.

SANTOS, J. S.; SOUZA, F. M.; SANTOS, M. L. P. Distribuição de $\mathrm{Zn}, \mathrm{Pb}, \mathrm{Ni}, \mathrm{Cu}, \mathrm{Mn}$ e Fe nas frações do sedimento superficial do Rio Cachoeira na região sul da Bahia, Brasil. Química Nova, 36: 236-239, 2013.

SAS INSTITUTE INC. SAS Online Doc 9,2. Cary, NC: SAS Institute Inc. 2010.

SILVA, J. A. M. F. et al. Mitigation of heavy metal contamination in soil via successive pig slurry applications. Soil and Sediment Contamination: An International Journal, 26: 675-690, 2017.

SOARES, M. R. Coeficiente de distribuição (Kd) de metais pesados em solos do estado de São Paulo. 2004. 202 f. Tese (Doutorado em Agronomia: Área de Concentração em Solos e Nutrição de Plantas) - Escola Superior de Agricultura "Luiz de Queiroz", Universidade de São Paulo, Piracicaba, 2004.

SOUSA, F. F. Fatores de transferência de metais pesados do solo para plantas de tomateiro cultivadas na região de Nova Friburgo, RJ. 2017. 130 f. Dissertação (Mestrado em Fitotecnia: Área de Concentração em Produção Vegetal) - Universidade
Federal Rural do Rio de Janeiro, Seropédica, 2017.

SOUZA, C. C. B. et al. Relation between changes in organic matter structure of poultry litter and heavy metals solubility during composting. Journal of Environmental Management, 247: 291-298, 2019.

STEVENSON, F. J. Humus chemistry: genesis, composition, reactions. 2. ed. New York, NY: John Wiley \& Sons, 1994. 512 p.

TESTA, M. Óleo de Cinnamomum zeylanicum no controle de Alphitobius diaperinus e ecotoxicidade da cama de aves contaminada com inseticidas em solos de Santa Catarina. 2018. 104 f. Dissertação (Mestrado em Zootecnia: Área de Concentração em Ciência e Produção Animal) - Universidade do Estado de Santa Catarina, Chapecó, 2018.

TRANI, P. E. et al. Avaliação da produtividade e qualidade comercial de quatro genótipos de tomate do tipo "cereja". In: WORKSHOP [DE] TOMATE NA UNICAMP: PESQUISA E TENDÊNCIAS, 2003, Campinas. Anais... Campinas, SP: UNICAMP, 2003. p. 82-83.

URE, A. M. et al. Speciation of Heavy Metals in Soils and Sediments. An Account of the Improvement and Harmonization of Extraction Techniques Undertaken Under the Auspices of the BCR of the Commission of the European Communities. International Journal of Environmental Analytical Chemistry, 51: 135$151,1993$.

UNITED STATES ENVIRONMENTAL PROTECTION AGENCY - USEPA. Method 3050B: acid digestion of sediments, sludges, and soils. 2. ed. Washington, DC: USEPA, 1996. 12 p.

VIEIRA, L. P. Acumulação de nutrientes e metais pesados em solo, água $\mathrm{e}$ hortaliças em áreas cultivadas com olerícolas no agreste de Pernambuco. 2011. 114 f. Dissertação (Mestrado em Ciência do Solo: Área de Concentração em Solos e Meio Ambiente) - Universidade Federal de Pernambuco, Recife, 2011.

WU, S. et al. Levels and health risk assessments of heavy metals in urban soils in Dongguan, China. Journal of Geochemical Exploration, 148: 71-78, 2015.

ZOFFOLI, H. J. O. et al. Inputs of heavy metals due to agrochemical use in tobacco fields in Brazil's Southern Region. Environmental Monitoring and Assessment, 185: 2423-2437, 2013. 